\title{
DEVELOPMENT OF A NORTH AMERICAN SOUTHERN MIDCONTINENT SILURIAN (UPPER LLANDOVERY-WENLOCK) COMPOSITE, CORRELATION WITH A GLOBAL SILURIAN COMPOSITE, AND IMPLICATIONS FOR WENLOCK CONODONT ZONES AND CONODONT PHYLOGENY
}

KLEFFNER*, Mark A., Dept. of Geological Sciences, The Ohio State University at Lima, 4240 Campus Drive, Lima, OH 45804-3576, U.S.A.; BARRICK, James E., Dept. of Geosciences, Texas Tech University, Box 41053, Lubbock, TX 79409-1053, U.S.A.

Ranges of 29 conodont species in 16 stratigraphic sections in Oklahoma, Texas, Arkansas, Missouri, Tennessee, and Illinois provided the data necessary to develop a North American southern midcontinent Silurian composite (SMSC) using the graphic correlation method. The Highway 77, Oklahoma section of Barrick and Klapper (1976) was selected as the standard reference section (SRS) because it was meticulously sampled and contained representatives of most of the diagnostic upper Llandovery/Wenlock conodont species. Additional Oklahoma stratigraphic sections were ranked and composited next because of their proximity and lithological similarity to the SRS and familiarity to the compositor. Stratigraphic sections outside of Oklahoma were also ranked and then composited to complete the initial round of correlation for the SMSC. The SMSC reached stability at the end of seven recorrelation rounds. The first appearance datums (FADs) of Kockelella amsdeni, $K$. patula, $K$. stauros, $K$. variabilis, $K$. walliseri, Ozarkodina sagitta rhenana, Pterospathodus procerus, and Belodella silurica and the last appearance datums (LADs) of Distomodus staurognathoides and P. amorphognathoides were important in helping to determine placement of lines of correlation (LOCs) during the initial and subsequent rounds of correlation/recorrelation.

The SMSC provides a quantitative framework which can be used to evaluate the utility of several Wenlock conodont zones important in the correlation of strata in the North American southern midcontinent. The SMSC also provides a more robust, comprehensive data framework for strata in the North American southern midcontinent than several of the individual sections comprising it which are also a part of a global conodont- and graptolite-based Silurian composite standard (CS) developed by Kleffner $(1989,1995)$. In order to further refine and improve the CS, the SMSC was graphically correlated with it, resulting in revision of several Wenlock conodont ranges. FADs and LADs of several diagnostic species were modified, requiring recorrelation of the CS. The stabilized, revised CS provides a quantitative framework which was used to examine phylogenies proposed for Kockelella and Ozarkodina. Several species assigned to those two genera are important in Wenlock conodont biostratigraphy and correlation in the North American southern midcontinent and elsewhere. 